\title{
LANZAIOPSIS BOLE, 1989 (CAENOGASTROPODA: TRUNCATELLOIDEA): ITS PHYLOGENETIC AND ZOOGEOGRAPHIC RELATIONSHIPS
}

\author{
SimONA PREVORČNiK ${ }^{1}$, SEBASTIAN HOFMAN²${ }^{2}$, TEO DELIĆ ${ }^{1}$, AleKSANDRA RYSIEWSKA ${ }^{3}$, \\ ARTUR OSIKOWSKI ${ }^{4}$, ANDRZEJ FALNIOWSKI ${ }^{3 *}$
}

\begin{abstract}
${ }^{1}$ Department of Biology, Biotechnical Faculty, University of Ljubljana, Jamnikarjeva 101, 1000 Ljubljana, Slovenia; TD (1) https://orcid.org/0000-0003-4378-5269

${ }^{2}$ Department of Comparative Anatomy, Institute of Zoology and Biomedical Research, Jagiellonian University, Gronostajowa 9, 30-387 Cracow, Poland; (1) https://orcid.org/0000-0001-6044-3055 ${ }^{3}$ Department of Malacology, Institute of Zoology and Biomedical Research, Jagiellonian University, Gronostajowa 9, 30-387 Cracow, Poland (e-mail: andrzej.falniowski@uj.edu.pl);

AR (1) https://orcid.org/0000-0002-9395-9696, AF @i) https://orcid.org/0000-0002-3899-6857 ${ }^{4}$ Department of Animal Reproduction, Anatomy and Genomics, Institute of Veterinary Science, University of Agriculture in Krakow, Cracow, Poland; (1) https://orcid.org/0000-0001-6646-2687 *corresponding author
\end{abstract}

\begin{abstract}
Lanzaiopsis savinica was collected from the type locality. The shell as well as the sculpture of the proto- and teleoconch are presented. Mitochondrial cytochrome oxidase subunit I (COI) and nuclear histone 3 (H3) gene sequences were used to infer phylogeny. Lanzaiopsis clearly belongs to the Moitessieriidae but it is only distantly related to Lanzaia. Its sister clade is Moitessieria, while Bythiospeum is the sister clade of the one formed by Lanzaiopsis and Moitessieria. To our knowledge, Lanzaiopsis is the first representative of the moitessieriid non-Balkan clade whose range is so close to the Balkans.
\end{abstract}

KEY WORDS: genus distinctness, Moitessieriidae, COI, H3, Balkans, shell sculpture, molecular phylogeny

\section{INTRODUCTION}

Lanzaiopsis Bole, 1989 is a monotypic genus introduced for a species reported from Slovenia: L. savinica Bole, 1989. Earlier, BOLE \& VELKOVRH (1984) introduced Lanzaia savinica as nomen nudum. The type locality of L. savinica is: "Kraški izvir Pečovski studenec, $1.6 \mathrm{~km}$ severozahodno od Luč v Savinjski dolini (Savinjske Alpe)" [karstic spring Pečovski izvir north-west of Luče in the Savinja Valley] (Bole 1989: 67). Its empty shells were collected also in nearby springs: a permanent spring about $100 \mathrm{~m}$ southeast of the bridge across the river Savinja (on its left bank) and deposits of temporary springs located 100-200 m north of the bridge (also on the left bank), as well as sand deposits in the cave Zavratnikova zijalka, about $1 \mathrm{~km}$ north of Pečovski studenec (BOLE 1989). The species was not found elsewhere (SLAPNIK 2011). As is the case with most stygobiotic snails, the number of empty shells found far exceeds the few finds of live specimens. In two summer seasons with extremely low water levels only three males and four females were found (BOLE 1989) alongside hundreds of empty shells. The species is included in the Hydrobiidae Troschel, 1857, Belgrandiellinae Radoman, 1983 (e.g. BOLE 1989, KABAT \& HERSHLER 1993, BANK \& NEUBERT 2017). According to BODON et al. (1996), Lanzaiopsis may become a junior synonym of Lanzaia Brusina, 1906. The aim of our paper was to establish phylogenetic relationships of Lanzaiopsis, applying molecular markers. 


\section{MATERIAL AND METHODS}

Specimens of Lanzaiopsis were collected from the type locality: spring Pečovski izvir, Luče, Ljubno ob Savinji, Slovenia; 46² $21^{\prime} 56^{\prime \prime} \mathrm{N}, 1^{\circ} 43^{\prime} 55^{\prime \prime E}$. Two live specimens and dozens of empty shells were found. The material was fixed in $96 \%$ ethanol changed twice, and later stored in $96 \%$ ethanol.

The shells were cleaned with an ultrasonic cleaner, and examined using a HITACHI S-4700 scanning electron microscope, applying the techniques described by FALNIOWSKI (1990).

The tissue was hydrated in TE buffer $(3 \times 10 \mathrm{~min})$; then total genomic DNA was extracted with the SHERLOCK extracting kit (A\&A Biotechnology), and the final product was dissolved in $20 \mu \mathrm{l}$ TE buffer. The extracted DNA was stored at $-80{ }^{\circ} \mathrm{C}$ at the Department of Malacology, Institute of Zoology and Biomedical Research, Jagiellonian University in Kraków (Poland). Mitochondrial cytochrome oxidase subunit I (COI) and nuclear histone 3 (H3) loci were sequenced. Details of PCR conditions, primers used and sequencing were given in SZAROWSKA et al. (2016).

Sequences were initially aligned in the MUSCLE (EDGAR 2004) program in MEGA 6 (TAMURA et al. 2013) and then checked in BIOEDIT 7.1.3.0 (HALL 1999). The saturation test (XIA 2000, XIA et al. 2003) was performed using DAMBE (XIA 2013). In the phylogenetic analysis additional sequences from GenBank were used (Table 1). The data were analysed using approaches based on Bayesian Inference
(BI) and Maximum Likelihood (ML). We applied the GTR model, whose parameters were estimated by the RaxML (STAMATAKIS 2014). The Bayesian analyses were run using MrBayes v. 3.2.3 (RONQUIST et al. 2012) with the default priors. The Maximum Likelihood analysis was conducted in RAxML V. 8.2.12 (STAMATAKIS 2006) using the 'RAxML-HPC v.8 on XSEDE (8.2.12)' tool via the CIPRES Science Gateway (MILLER et al. 2010). We selected the GTRGAMMA nucleotide substitution model, empirical stationary base frequencies and proportion of invariant sites.

To apply the molecular clock, we used the data from COI. Sequences of two hydrobiids, Peringia ulvae Pennant, 1777 and Salenthydrobia ferreri Wilke, 2003 deposited in GenBank by WILKE (2003) as AF478401 and AF478410, respectively, were used as outgroups (tree not shown). The divergence time between these two species was used to calibrate the molecular clock, with correction according to FALNIOWSKI et al. (2008). The likelihoods for trees with and without the molecular clock assumption for a likelihood ratio test (LRT) (NEI \& KUMAR 2000) were calculated with PAUP (SWOFFORD 2002). The relative rate test (RRT) (TAJIMA 1993) was performed in MEGA. As Tajima's RRTs and the LRT test rejected the equal evolutionary rate throughout the tree, time estimates were calculated using a non-parametric rate smoothing (NPRS) analysis with the recommended Powell algorithm, in r8s v.1.7 for Linux (SANDERSON 1997, 2003).

Table 1. Taxa used for phylogenetic analyses with their GenBank accession numbers and references

\begin{tabular}{|c|c|c|c|}
\hline \multirow{2}{*}{ Species } & \multicolumn{2}{|c|}{ Gen Bank numbers } & \multirow{2}{*}{ References } \\
\hline & COI & $\mathrm{H} 3$ & \\
\hline \multirow{2}{*}{ Agrafia wiktori Szarowska et Falniowski, 2011} & JF906762 & & SZAROWSKA \& FALNIOWSKI 2011 \\
\hline & & MG543158 & GREGO et al. 2017 \\
\hline Alzoniella finalina Giusti et Bodon, 1984 & AF367650 & & WILKE et al. 2001 \\
\hline Anagastina zetavalis (Radoman, 1973) & EF070616 & & SZAROWSKA 2006 \\
\hline Avenionia brevis berenguieri (Draparnaud, 1805) & AF367638 & & WILKE et al. 2001 \\
\hline \multirow[t]{2}{*}{ Belgrandiella kusceri (Wagner, 1914) } & KT218511 & & FALNIOWSKI \& BERAN 2015 \\
\hline & & MG551366 & OsIKOWSKI et al. 2018 \\
\hline Bithynia tentaculata (Linnaeus, 1758) & AF367643 & & WiLKE et al. 2001 \\
\hline Bythinella austriaca (von Frauenfeld, 1857) & JQ639858 & & FALNIOWSKI et al. 2012b \\
\hline Bythinella micherdzinskii Falniowski, 1980 & JQ639854 & & FALNIOWSKI et al. 2012b \\
\hline \multirow[t]{2}{*}{ Bythiospeum acicula (Hartmann, 1821) } & KU341350 & & RICHLING et al. 2016 \\
\hline & & MK609534 & FALNIOWSKI et al. 2019 \\
\hline Bythiospeum alzense Boeters, 2001 & KU341354 & & RICHLING et al. 2016 \\
\hline Dalmatinella fluviatilis Radoman, 1973 & KC344541 & & FALNIOWSKI \& SZAROWSKA 2013 \\
\hline Daphniola louisi Falniowski et Szarowska, 2000 & KM887915 & & SZAROWSKA et al. 2014a \\
\hline \multirow[t]{2}{*}{ Ecrobia maritima (Milaschewitsch, 1916) } & KJ406200 & & SZAROWSKA \& FALNIOWSKI 2014b \\
\hline & & MG551322 & GREGO et al. 2017 \\
\hline Emmericia expansilabris Bourguignat, 1880 & KC810060 & & SZAROWSKA \& FALNIOWSKI 2013a \\
\hline
\end{tabular}


Table 1. continued

\begin{tabular}{|c|c|c|c|}
\hline \multirow{2}{*}{ Species } & \multicolumn{2}{|c|}{ Gen Bank numbers } & \multirow{2}{*}{ References } \\
\hline & COI & $\mathrm{H} 3$ & \\
\hline Fissuria boui Boeters, 1981 & AF367654 & & WILKE et al. 2001 \\
\hline $\begin{array}{l}\text { Graecoarganiella parnassiana Falniowski } \\
\text { et Szarowska, } 2011\end{array}$ & JN202352 & & FALNIOWSKI \& SZAROWSKA 2011 \\
\hline Graziana alpestris (Frauenfeld, 1863) & AF367641 & & WILKE et al. 2001 \\
\hline Grossuana codreanui (Grossu, 1946) & EF061919 & & SZAROWSKA et al. 2007 \\
\hline Hauffenia tellinii (Pollonera, 1898) & KY087861 & & RYSIEWSKA et al. 2017 \\
\hline Hauffenia michleri Kuščer, 1932 & KY087865 & KY087878 & RYSIEWSKA et al. 2017 \\
\hline Heleobia dalmatica (Radoman, 1974) & AF129321 & & HERSHLER et al. 1999 \\
\hline Heleobia dobrogica (Grossu et Negrea, 1989) & EU938131 & & FALNIOWSKI et al. 2008 \\
\hline \multirow[t]{2}{*}{ Heleobia maltzani (Westerlund, 1886) } & KM213723 & & SZAROWSKA et al. 2014b \\
\hline & & MK629762 & FALNIOWSKI et al. 2019 \\
\hline Horatia klecakiana Bourguignat 1887 & KJ159128 & & SZAROWSKA \& FALNIOWSKI 2014a \\
\hline Hydrobia acuta (Draparnaud, 1805) & AF278808 & & WILKE et al. 2000 \\
\hline Iglica cf. gracilis (Clessin, 1882) & $\begin{array}{l}\text { MH720985- } \\
\text { MH720989 }\end{array}$ & $\begin{array}{l}\text { MH721002- } \\
\text { MH721004 }\end{array}$ & HOFMAN et al. 2018 \\
\hline Iglica cf. hauffeni (Brusina, 1886) & & MH720995 & HOFMAN et al. 2018 \\
\hline Iglica cf. forumjuliana (Pollonera, 1887) & & MH721006 & HOFMAN et al. 2018 \\
\hline \multirow[t]{2}{*}{ Iglica hellenica Falniowski et Sarbu, 2015} & KT825581 & & FALNIOWSKI \& SARBU 2015 \\
\hline & & MH721007 & HOFMAN et al. 2018 \\
\hline \multirow[t]{2}{*}{ Islamia zermanica (Radoman, 1973) } & KU662362 & & BERAN et al. 2016 \\
\hline & & MG551320 & GREGO et al. 2017 \\
\hline Lanzaia bosnica Bole, 1970 & & MH721021 & HOFMAN et al. 2018 \\
\hline Lanzaiopsis savinica Bole, 1989 & $\begin{array}{l}\text { MN272428- } \\
\text { MN272429 }\end{array}$ & $\begin{array}{l}\text { MN272430- } \\
\text { MN272431 }\end{array}$ & This paper \\
\hline Lithoglyphus prasinus (Küster, 1852) & JX073651 & & FALNIOWSKI \& SZAROWSKA 2012 \\
\hline \multirow[t]{2}{*}{ Littorina littorea (Linnaeus, 1758) } & KF644330 & & LAYTON et al. 2014 \\
\hline & & KP113574 & NERETINA 2014, unpublished \\
\hline Marstoniopsis insubrica (Küster, 1853) & AF322408 & & FALNIOWSKI \& WILKE 2001 \\
\hline \multirow[t]{2}{*}{ Moitessieria cf. puteana Coutagne, 1883} & AF367635 & & WILKE et al. 2001 \\
\hline & & MH721012 & HoFMAN et al. 2018 \\
\hline \multirow[t]{2}{*}{ Montenegrospeum bogici (Pešić et Glöer, 2012) } & KM875510 & & FALNIOWSKI et al. 2014 \\
\hline & & MG880218 & GREGO et al. 2018 \\
\hline Paladilhiopsis cf. absoloni (A. J. Wagner, 1914) & & MH721021 & HOFMAN et al. 2018 \\
\hline Paladilhiopsis blihensis (Glöer et Grego, 2015) & & MH721015 & HOFMAN et al. 2018 \\
\hline Paladilhiopsis bosniaca (Clessin, 1910) & & MH721020 & HOFMAN et al. 2018 \\
\hline Paladilhiopsis grobbeni Kuščer, 1928 & MH720991 & MH721014 & HOFMAN et al. 2018 \\
\hline Paladilhiopsis turrita (Kuščer, 1933) & MH720992 & MH721015 & HOFMAN et al. 2018 \\
\hline $\begin{array}{l}\text { Paladilhiopsis gittenbergeri (A. Reischutz } \\
\text { et P. L. Reischutz, 2008) }\end{array}$ & MH720993 & MH721025 & HOFMAN et al. 2018 \\
\hline Paladilhiopsis maroskoi (Glöer et Grego, 2015) & & MH721017 & HOFMAN et al. 2018 \\
\hline Peringia ulvae (Pennant, 1777) & AF118302 & & WILKE \& DAVIS 2000 \\
\hline \multirow[t]{2}{*}{ Pontobelgrandiella sp. Radoman, 1978} & KU497024 & & RYSIEWSKA et al. 2016 \\
\hline & & MG551321 & GREGO et al. 2017 \\
\hline Pseudamnicola sp. Paulucci, 1878 & & KT710579 & SZAROWSKA et al. 2016 \\
\hline Radomaniola curta (Küster, 1853) & KC011814 & & FALNIOWSKI et al. 2012a \\
\hline Sadleriana fluminensis (Küster, 1853) & KF193067 & & SZAROWSKA \& FALNIOWSKI 2013b \\
\hline Salenthydrobia ferrerii Wilke, 2003 & AF449213 & & WILKE 2003 \\
\hline Tanousia zrmanjae (Brusina, 1866) & KU041812 & & BERAN et al. 2015 \\
\hline
\end{tabular}




\section{RESULTS AND DISCUSSION}

The shell of Lanzaiopsis savinica (Figs 1-2) is turriform, with characteristically shaped aperture surrounded by a broad, continuous and folded lip. The protoconch (Figs 3-4) is smooth, all the teleoconch covered with characteristic macrosculpture (Figs 5-6), composed of prominent radial growth lines, and spiral cords. This macrosculpture resembles the one visible in Costellina turrita Kuščer, 1933, Lanzaia bosnica Bole, 1970, or Paladilhiopsis bosniaca (Clessin, 1910), but not the one characteristic of Moitessieria Bourguignat, 1863 (HOFMAN et al. 2018). The microsculpture of the teleoconch (Figs 7-8) is composed of irregularly distributed small pores, resembling the ones found in Marstoniopsis van Regteren Altena, 1936, and Dianella Gude, 1913 (FALNIOWSKI \& SZAROWSKA 1995).

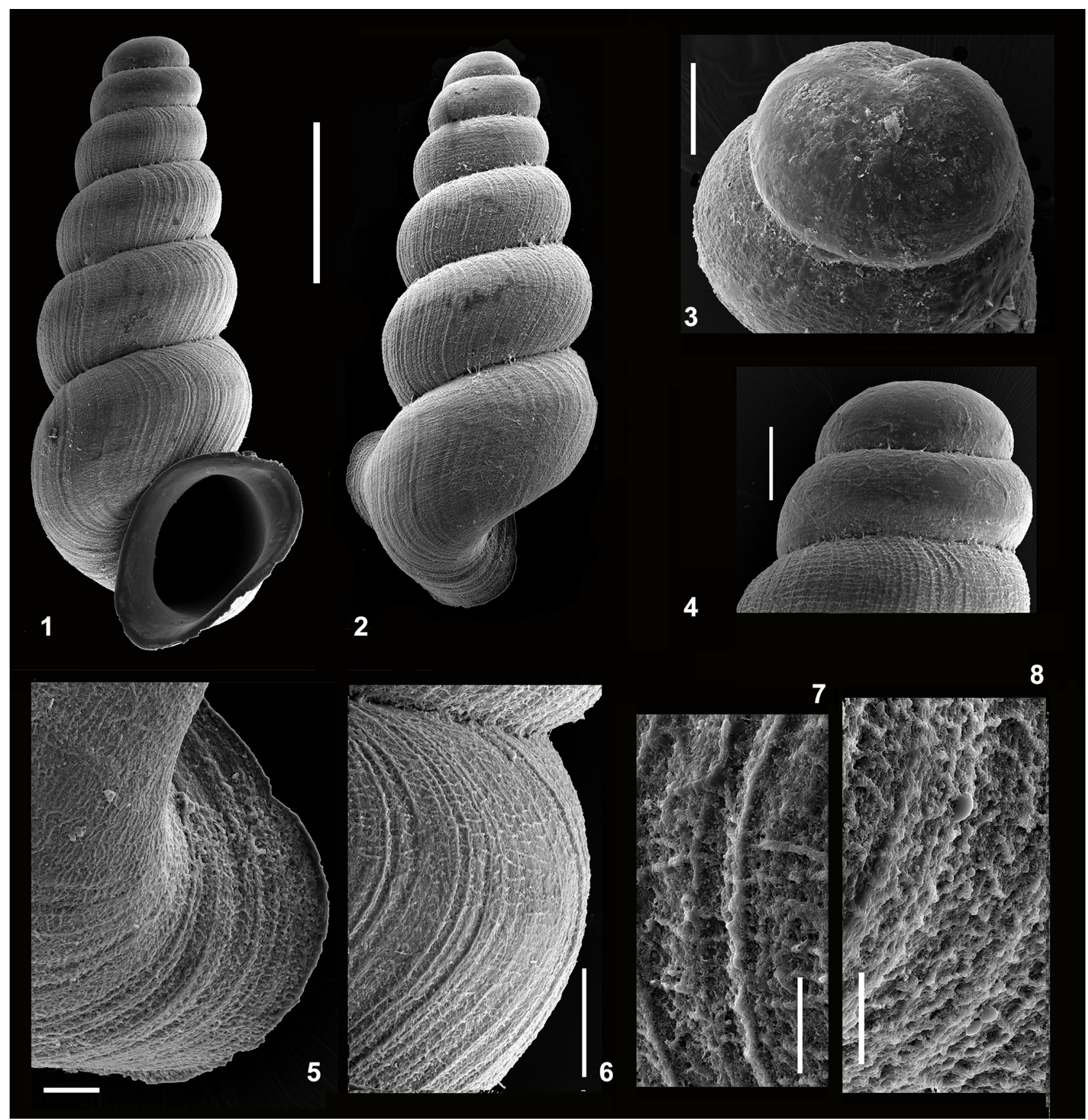

Figs 1-8: Shell of Lanzaiopsis savinica: 1-2 - shell habitus (scale bar $500 \mu \mathrm{m}), 3-4$ - protoconch (scale bars $100 \mu \mathrm{m}$ ), 5 - lip from the outer side (scale bar $50 \mu \mathrm{m}$ ), 6 - body whorl macrosculpture (scale bar $100 \mu \mathrm{m}$ ), 7-8 - body whorl microsculpture (scale bar $25 \mu \mathrm{m}$ ) 
The anatomy of the genus Lanzaia was described by BOLE (1970) on the basis of $L$. vjetrenicae Kuščer, 1933 and L. bosnica Bole, 1970. Lanzaiopsis was distinguished from Lanzaia by several traits: in Lanzaiopsis the bursa copulatrix is proportionally bigger, the receptaculum ( $\mathrm{rs}_{1}$, distal one) smaller, the accessory gland complex of the female reproductive organs divided in two sections, but not folded, and the penis triangular and relatively short (BOLE 1989). The shell of Lanzaiopsis, conical and elongated, with strongly expanded, peristome and very oblique aperture axis resembles the shell of Lanzaia, except for the less prominent radial sculpture and spiral microsculpture (BOLE 1989).

Our COI tree (Fig. 9) (GenBank Accession numbers MN272428-MN272429) clearly confirmed the systematic position of Lanzaiopsis within the Moitessieriidae Bourguignat, 1863, not within the Hydrobiidae, Belgrandiellinae, as postulated by numerous authors (e.g. BOLE 1989, KABAT \& HERSHLER 1993, BANK \& NEUBERT 2017). The sister clade of Lanzaiopsis is Moitessieria. Both genera form a well supported (bootstrap support $75 \%$, Bayesian probability 1.0) clade, close to Bythiospeum Bourguignat, 1882. The COI-based tree does not confirm the monophyly of the Moitessieriidae, with the Cochliopidae Tryon, 1866 falling between the two main moitessieriid clades (although bootstrap supports were low), as already reported by HOFMAN at al. (2018) and FALNIOWSKI et al. (2019). The inclusion of the nuclear histone H3 sequences (Fig. 10) (GenBank Accession numbers MN272430-MN272431), how-

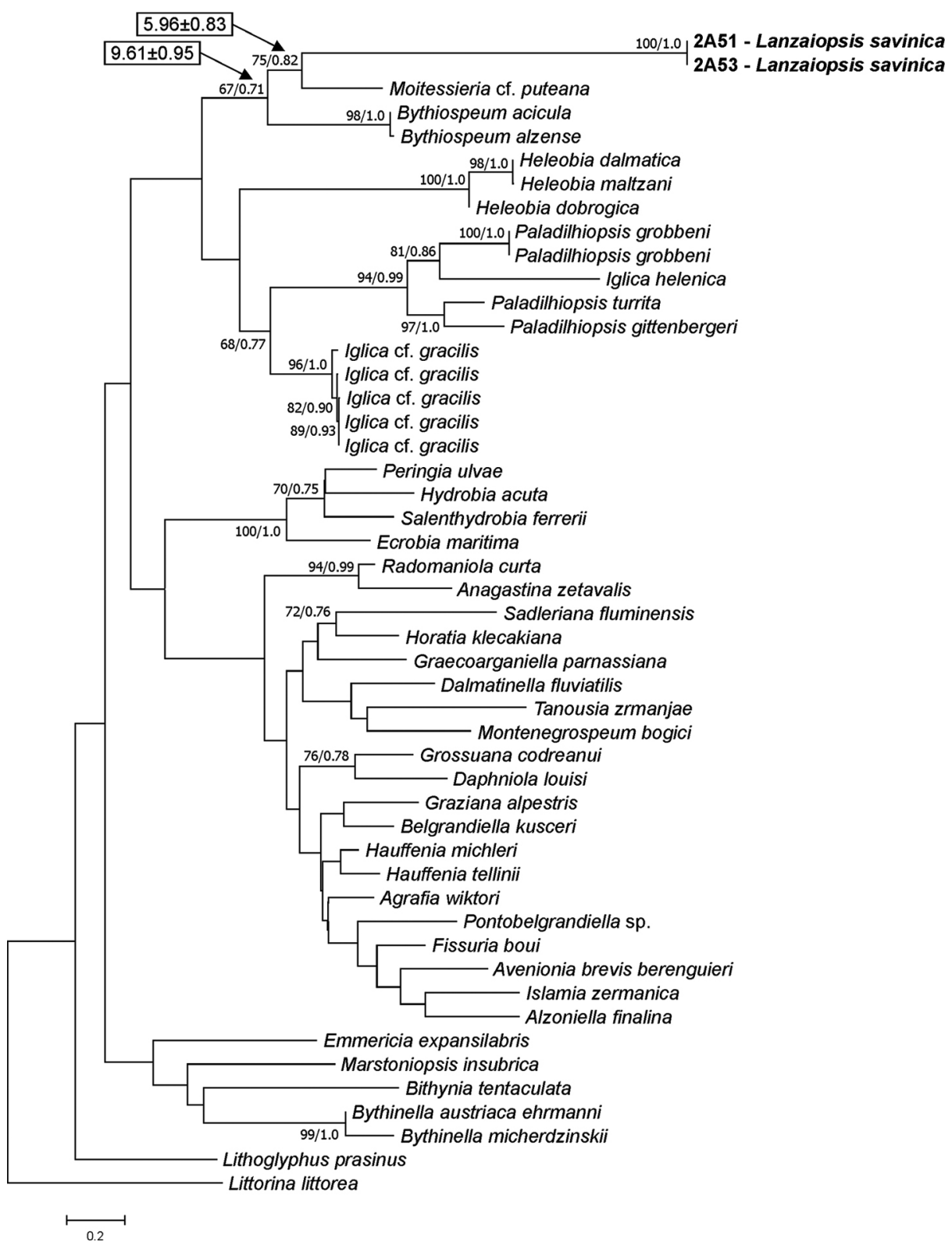

Fig. 9. Maximum Likelihood tree inferred from mitochondrial cytochrome oxidase subunit I (COI). Bootstrap supports and Bayesian probabilities given 
ever, resulted in confirmation of the moitessieriid monophyly in both the $\mathrm{H} 3$ tree (bootstrap support $75 \%$, Fig. 10) and the tree computed for the two concatenated sequences (bootstrap support 75\%, Fig. 11), similarly as demonstrated in FALNIOWSKI et al. (2019). In all three trees, the sister clade of Lanzaiopsis is Moitessieria, with p-distances 0.225 for $\mathrm{COI}$ and 0.065 for $\mathrm{H} 3$, which are typical of the truncatelloid genus-level. The p-distance in $\mathrm{H} 3$ between
Lanzaiopsis and Lanzaia (represented in our phylogeny as Paladilhiopsis (Lanzaia) bosnica) is 0.106, which refutes the suggestion of BODON et al. (1996) that both taxa represent the same genus.

The reconstructed phylogeny presents also an interesting zoogeographic aspect. Within the European Moitessieriidae, two markedly distinct clades could be distinguished: the one consisting of Bythiospeum and Moitessieria, and the second including Iglica Wagner,

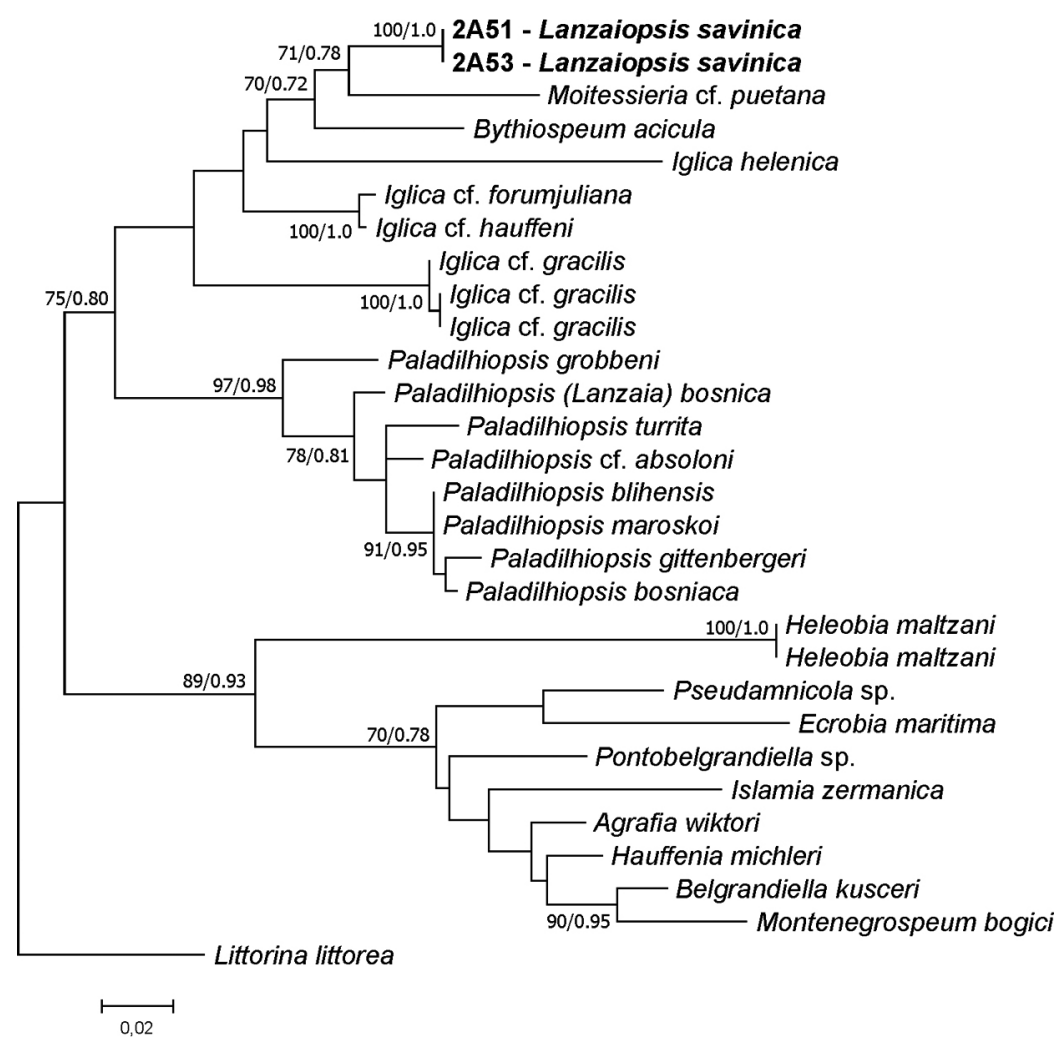

Fig. 10. Maximum Likelihood tree inferred from nuclear histone H3. Bootstrap supports and Bayesian probabilities given (if above $70 \% / 0.7$ )

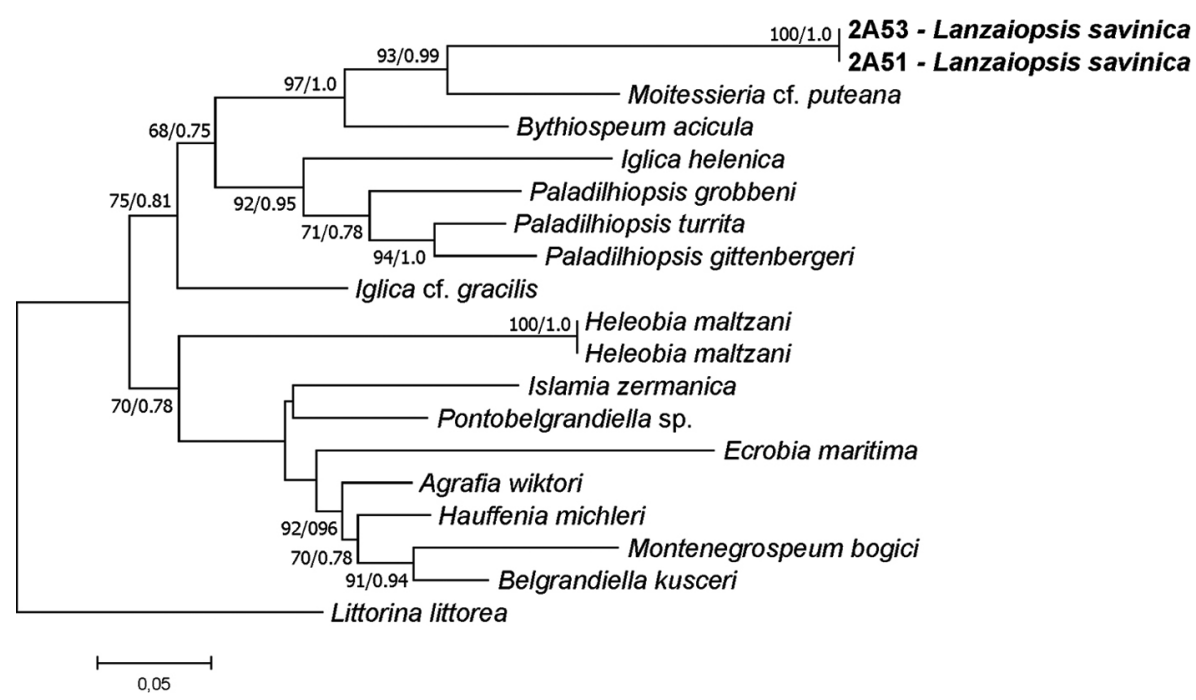

Fig. 11. Maximum Likelihood tree inferred from concatenated COI and H3 sequence. Bootstrap supports and Bayesian probabilities given (if above 70\%/0.7) 
1927, Paladilhiopsis Pavlovic, 1913 and Lanzaia. While representatives of the former clade were found only in subterranean habitats in central and southern Europe (Germany, Switzerland, Austria, Italy, France) so far, i.e. outside the Balkans, the latter inhabit the Balkans, but also Hungary and Romania. The single known locality of Lanzaiopsis, although outside the Balkans, is within the range of this second, Balkan clade, and geographically is close to the Balkans. On the other hand, its locality belongs to a young Alpine arch named Southern Calcareous Alps, not to the Dinarides.

Despite the sister-clade relationships between Lanzaiopsis and Moitessieria, the divergence between those two taxa took place rather long time ago. The application of molecular clock resulted in estima-

\section{REFERENCES}

BANK R. A., Neubert E. 2017. Mollusca Base: Checklist of the land and freshwater Gastropoda of Europe. http://www.molluscabase.org/aphia.php?p=sourcedetails\&id=279050. Last update: July 16th, 2017.

BERAN L., HofmAN S., FALNIOWSKI A. 2015. Tanousia zrmanjae (Brusina, 1866) (Caenogastropoda: Truncatelloidea: Hydrobidae): A living fossil. Folia Malacologica 23: 263-271. https://doi.org/10.12657/folmal.023.022

BERAN L., OsIKOWSKI A., HOFMAN S., FALNIOWSKI A. 2016. Islamia zermanica (Radoman, 1973) (Caenogastropoda: Hydrobidae): morphological and molecular distinctness. Folia Malacologica 24: 25-30. https://doi. org/10.12657/folmal.024.004

Bodon M., Manganelli G., GiUsti F. 1996. A new hydrobiid from subterranean waters of the Timavo River (Friuli-Venetia Julia, NE. Italy) (Gastropoda Prosobranchia: Hydrobiidae). Basteria 60: 27-39.

BOLE J. 1970. Prispevek k poznavanju anatomije in taksonomije podzemeljskih hidrobiid (Gastropoda, Prosobranchia). Razprave IV. razredu SAZU, Ljubljana, 13: 75-108.

BOLE J. 1989. Lanzaiopsis savinica gen. n. sp. n. (Gastropoda, Belgrandiellidae), novi podzemeljski polž iz Savinjsken Doline (Savinjske Alpe). Slovenska Akademia Znanosti in Umetnosti, Razprave 30: 65-74.

Bole J., VelKovrh F. 1984. Mollusca from continental subterranean aquatic habitats. In: BOTOSANEANU L. (ed.) Stygofauna Mundi: A faunistic, distributional, and ecological synthesis of the World Fauna inhabiting subterranean waters (Including the Marine Interstitial), E. J. Brill, Leiden, pp. 177-208.

EDGAR R. C. 2004. MUSCLE: multiple sequence alignment with high accuracy and high throughput. Nucleic Acids Research 32: 1792-1797. https://doi.org/10.1093/nar/ gkh340

FALNIOWSKI A. 1990. Anatomical characters and SEM structure of radula and shell in the species-level taxonomy of freshwater prosobranchs (Mollusca: Gastropoda: tion of the time of divergence as $5.96 \pm 0.83$ Mya (Fig. 11). This is the latest Miocene, around the time of the Messinian Salinity Crisis. The closure of the present Strait of Gibraltar resulted in desiccation of the Mediterranean Sea, thus the climate became drier and hotter (HsÜ 1983, KRIJGSMAN et al. 1999, GARCIA-CASTELLANOS et al. 2009). This probably resulted in extinction of the cold water fauna within a large area, possibly isolating the ancestors of the two genera in distant refuges.

\section{ACKNOWLEDGEMENTS}

The study was supported by a grant from the National Science Centre 2017/25/B/NZ8/01372 to ANDRZEJ FALNIOWSKI.
Prosobranchia): a comparative usefulness study. Folia Malacologica 4: 53-142. https://doi.org/10.12657/folmal.004.005

FAlNiOWSKI A., BERAN L. 2015. Belgrandiella A. J. Wagner, 1928 (Caenogastropoda: Truncatelloidea: Hydrobiidae): how many endemics? Folia Malacologica 23: 187-191. https://doi.org/10.12657/folmal.023.015

FALNIOWSKI A., PEŠIĆ V., GLÖER P. 2014. Montenegrospeum Pešić et Glöer, 2013: a representative of Moitessieriidae? Folia Malacologica 22: 263-268. https://doi. org/10.12657/folmal.022.023

FAlniowski A., PrevorČniK S., Delić T., Alther R., Altermatt F., Hofman S. 2019. Monophyly of the Moitessieriidae Bourguignat, 1863 (Caenogastropoda: Truncatelloidea). Folia Malacologica 27: 61-70. https:// doi.org/10.12657/folmal.027.005

FALNIOWSKI A., SARBU S. 2015. Two new Truncatelloidea species from Melissotrypa Cave in Greece (Caenogastropoda). ZooKeys 530: 1-14. https://doi. org/10.3897/zookeys.530.6137

FALNIOWSKI A., SZAROWSKA M. 1995. Can poorly understood new characters support a poorly understood phylogeny? Shell-structure data in Hydrobiid systematics (Mollusca: Gastropoda: Prosobranchia: Hydrobiidae). Journal of Zoological Systematics and Evolutionary Research 33: 133-144. https://doi. org/10.1111/j.1439-0469.1995.tb00221.x

FALNIOWSKI A., SZAROWSKA M. 2011. A new genus and new species of valvatiform hydrobiid (Rissooidea; Caenogastropoda) from Greece. Molluscan Research 31: 189-199.

FALNIOWSKI A., SZAROWSKA M. 2012. Species distinctness of Lithoglyphus prasinus (Küster, 1852) (Rissooidea: Caenogastropoda). Folia Malacologica 20: 99-104. https://doi.org/10.2478/v10125-012-0019-x

FALNIOWSKI A., SZAROWSKA M. 2013. Phylogenetic relationships of Dalmatinella fluviatilis Radoman, 1973 
(Caenogastropoda: Rissooidea). Folia Malacologica 21: 1-7. https://doi.org/10.12657/folmal.021.001

FALNIOWSKI A., SZAROWSKA M., GLÖER P., PEŠIĆ V. 2012a. Molecules vs morphology in the taxonomy of the Radomaniola/Grossuana group of Balkan Rissooidea (Mollusca: Caenogastropoda). Journal Conchology 41: 19-36.

FALNIOWSKI A., SZAROWSKA M., GLÖER P., PEŠIĆ V., GEORGIEV D., HorSAK M., SiRbU I. 2012b. Radiation in Bythinella (Mollusca: Gastropoda: Rissooidea) in the Balkans. Folia Malacologica 20: 1-10. https://doi. org/10.2478/v10125-012-0006-2

FALNIOWSKI A., SZAROWSKA M., SirbU I., Hillebrand A., BACIU M. 2008. Heleobia dobrogica (Grossu \& Negrea, 1989) (Gastropoda: Rissooidea: Cochliopidae) and the estimated time of its isolation in a continental analogue of hydrothermal vents. Molluscan Research 28: 165-170.

FALNIOWSKI A., WILKE T. 2001. The genus Marstoniopsis (Rissooidea: Gastropoda): intra- and intergeneric phylogenetic relationships. Journal of Molluscan Studies 67: 483-488. https://doi.org/10.1093/mollus/67.4.483

Grego J., Hofman S., Mumladze L., FALNiOWSKI A. 2017. Agrafia Szarowska et Falniowski, 2011 (Caenogastropoda: Hydrobiidae) in the Caucasus. Folia Malacologica 25: 237-247. https://doi.org/10.12657/ folmal.025.025

GrEgo J., GLÖER P., RYSIEWSKA A., HOFMAN S., FALNIOWSKI A. 2018. A new Montenegrospeum species from south Croatia (Mollusca: Gastropoda: Hydrobiidae). Folia Malacologica 26: 25-34. https://doi.org/10.12657/folmal.026.004

GARCIA-CASTELlanos D., ESTRADA F., JiMÉNEZ-MUNT I., GORINI C., FERNÀNDEZ M., VERGÉS J., DE VICENTE R. 2009. Catastrophic flood of the Mediterranean after the Messinian salinity crisis. Nature 462: 778-781. https:// doi.org/10.1038/nature08555

HALl T. A. 1999. BioEdit: a user-friendly biological sequence alignment editor and analysis program for Windows 95/98/NT. Nucleic Acids Symposium Series 41: 95-98.

Hershler R., LiU H. P., Mulvey M. 1999. Phylogenetic relationships within the aquatic snail genus Tryonia: implications for biogeography of the North American Southwest. Molecular Phylogenetic and Evolution 13: 377-391. https://doi.org/10.1006/mpev.1999.0659

HOFMAN S., RYSIEWSKA A., OSIKOWSKI A., GREGO J., SKET B., PREVORČNIK S., ZAGMAJSTER M., FALNIOWSKI A. 2018. Phylogenetic relationships of the Balkan Moitessieriidae (Caenogastropoda: Truncatelloidea). Zootaxa 4486: 311-339. https://doi.org/10.11646/zootaxa.4486.3.5

HsÜ K. J. 1983. The Mediterranean was a desert. Princeton University Press, Princeton (NJ).

KABAT A. R., HeRShleR R. 1993. The prosobranch snail family Hydrobiidae (Gastropoda: Rissooidea): review of classification and supraspecific taxa. Smithsonian Contributions to Zoology 547: 1-94.

Krijgsman W., Hilgen F. J., RafFi I., Sierro F. J., Wilson D. S. 1999. Chronology, causes and progression of the
Messinian salinity crisis. Nature 400: 652-655. https:// doi.org/10.1038/23231

Layton K. K., Martel A. L., Hebert P. D. 2014. Patterns of DNA barcode variation in Canadian marine molluscs. PLoS ONE 9: e95003. https://doi.org/10.1371/journal. pone.0095003

Miller M. A., Pfeiffer W., Schwartz T. 2010. Creating the CIPRES Science Gateway for inference of large phylogenetic trees. Proceedings of the Gateway Computing Environments Workshop (GCE), 14 Nov., New Orleans, LA: $1-8$

NeI M., KumAR S. 2000. Molecular evolution and phylogenetics. Oxford University Press, Oxford.

Neretina T. V. 2014. Littorina littorea isolate C histone H3 (H3) gene, partial cds - KP113574 unpublished. Available from https://www.ncbi.nlm.nih.gov/nuccore/ KP113574 (accessed 18 November 2017).

OsIKOWSKI A., HOFMAN S., RYSIEWSKA A., SKET B., PREVORČNIK S., FALNIOWSKI A. 2018. A case of biodiversity overestimation in the Balkan Belgrandiella A. J. Wagner, 1927 (Caenogastropoda: Hydrobiidae): molecular divergence not paralleled by high morphological variation. Journal of Natural History 52: 323-344. https://doi.org/10.1080/00222933.2018.1424959

Richling I., MALKOWSKY Y., KUHN Y., NIEDERHÖFER H.-J., BOETERS H. D. 2016. A vanishing hotspot - impact of molecular insights on the diversity of Central European Bythiospeum Bourguignat, 1882 (Mollusca: Gastropoda: Truncatelloidea). Organisms Diversity \& Evolution 17: 67-85. https://doi.org/10.1007/s13127-016-0298-y

RONQUist F., TESLENKO M., MARK P. VAN DER, AYRES D. L., DARling A., HÖHNA S., LARGET B., LiU L., SUCHARD M. A., HuelsenBECK J. P. 2012. Mr.Bayes 3.2: efficient Bayesian phylogenetic inference and model choice across a large model space. Systematic Biology 61: 539542. https://doi.org/10.1093/sysbio/sys029

RYSIEWSKA A., GEORGIEV D., OSIKOWSKI A., HOFMAN S., FALNIOWSKI A. 2016. Pontobelgrandiella Radoman, 1973 (Caenogastropoda: Hydrobiidae): A recent invader of subterranean waters? Journal of Conchology 42: 193203.

RYSIEWSKa A., PREVORČNIK S., OSIKOWSKI A., HOFMAN S., BERAN L., FALNIOWSKI A. 2017. Phylogenetic relationships in Kerkia and introgression between Hauffenia and Kerkia (Caenogastropoda: Hydrobiidae). Journal of Zoological Systematics and Evolutionary Research 55: 106-117. https://doi.org/10.1111/jzs.12159

SANDERSON M. J. 1997. A nonparametric approach to estimating divergence times in the absence of rate constancy. Molecular Biology and Evolution 14: 1218 1231. https://doi.org/10.1093/oxfordjournals.molbev. a003974

SANDERSON M. J. 2003. r8s: inferring absolute rates of molecular evolution, divergence times in the absence of a molecular clock. Bioinformatics 19: 301-302. https:// doi.org/10.1093/bioinformatics/19.2.301

SLAPNIK R. 2011. Lanzaiopsis savinica. The IUCN Red List of Threatened Species 2011: e.T155909A4864600. https://doi.org/10.2305/IUCN.UK.2011-2.RLTS. T155909A4864600.en. Downloaded on 05 April 2019. 
STAMATAKIS A. 2006. Raxml-vi-hpc: maximum likelihood-based phylogenetic analyses with thousands of taxa and mixed models. Bioinformatics 22: 2688-2690.

STAMATAKIS A. 2014. RAxML Version 8: a tool for phylogenetic analysis and post-analysis of large phylogenies. Bioinformatics 30: 1312-1313. https://doi. org/10.1093/bioinformatics/btu033

SWOFFORD D. L. 2002. PAUP*. Phylogenetic analysis using parsimony (*and other methods). Version 4. [Computer software and manual]. Sinauer Associates Inc., Sunderland, Massachusetts.

SZAROWSKA M. 2006. Molecular phylogeny, systematics and morphological character evolution in the Balkan Rissooidea (Caenogastropoda). Folia Malacologica 14: 99-168. https://doi.org/10.12657/folmal.014.014

SZAROWSKA M., FALNIOWSKI A. 2011. An unusual, flagellum-bearing hydrobiid snail (Gastropoda: Rissooidea: Hydrobiidae) from Greece, with descriptions of a new genus and a new species. Journal of Natural History 45: 2231-2246. https://doi.org/10.1080/00222933.20 11.591067

SZAROWSKA M., FALNIOWSKI A. 2013a. Phylogenetic relationships of the Emmericiidae (Caenogastropoda: Rissooidea). Folia Malacologica 21: 67-72. https://doi. org/10.12657/folmal.021.007

SZAROWSKA M., FALNIOWSKI A. 2013b. Species distinctness of Sadleriana robici (Clessin, 1890) (Gastropoda: Rissooidea). Folia Malacologica 21: 127-133. https:// doi.org/10.12657/folmal.021.016

SZAROWSKA M., FALNIOWSKI A. 2014a. Horatia Bourguignat, 1887: is this genus really phylogenetically very close to Radomaniola Szarowska, 2006 (Caenogastropoda: Truncatelloidea)? Folia Malacologica 22: 31-39. https:// doi.org/10.12657/folmal.022.003

SZAROWSKA M., FALNIOWSKI A. 2014b. Ventrosia mariti$m a$ (Milaschewitsh, 1916) and V. ventrosa (Montagu, 1803) in Greece: molecular data as a source of information about species ranges within the Hydrobiinae (Caenogastropoda: Truncatelloidea). Folia Malacologica 22: 61-67. https://doi.org/10.12657/folmal.022.006

SZAROWSKA M., GRZMIL P., FALNIOWSKI A., SIRBU I. 2007. Grossuana codreanui (Grossu, 1946) and the phylogenetic relationships of the East Balkan genus Grossuana (Radoman, 1973) (Gastropoda: Rissooidea). Hydrobiologia 579: 379-391. https://doi.org/10.1007/ s10750-006-0530-4

SZAROWSKa M., HOFMAN S., OSIKOWSKI A., FALNIOWSKI A. 2014a. Daphniola Radoman, 1973 (Caenogastropoda: Truncatelloidea) at east Aegean islands. Folia Malacologica 22: 269-275. https://doi.org/10.12657/ folmal.022.021

SZAROWSKA M., HOFMAN S., OSIKOWSKI A., FALNIOWSKI A. 2014b. Heleobia maltzani (Westerlund, 1886) (Caenogastropoda: Truncatelloidea: Cochliopidae) from Crete and species-level diversity of Heleobia Stimpson, 1865 in Europe. Journal of Natural History
48: 2487-2500. https://doi.org/10.1080/00222933.20 14.946109

SZAROWSKA M., OSIKOWSKI A., HOFMAN S., FALNIOWSKI A. 2016. Pseudamnicola Paulucci, 1878 (Caenogastropoda: Truncatelloidea) from the Aegean Islands: a long or short story? Organisms Diversity \& Evolution 16: 121139. https://doi.org/10.1007/s13127-015-0235-5

TAJIMA F. 1993. Simple methods for testing molecular clock hypothesis. Genetics 135: 599-607.

Tamura K., Peterson D., Peterson N., Stecher G., Nei M., KUMAR S. 2013. MEGA5: Molecular evolutionary genetics analysis using maximum likelihood, evolutionary distance, and maximum parsimony method. Molecular Biology and Evolution 28: 2731-2739. https://doi.org/10.1093/molbev/msr121

WILKE T. 2003. Salenthydrobia gen. nov. (Rissooidea: Hydrobiidae): a potential relict of the Messinian Salinity Crisis. Zoological Journal of the Linnean Society 137: 319-336. https://doi.org/10.1046/j.1096 3642.2003.00049.x

WiLKE T., DAVIS G. M. 2000. Infraspecific mitochondrial sequence diversity in Hydrobia ulvae and Hydrobia ventrosa (Hydrobiidae: Rissoacea: Gastropoda): Do their different life histories affect biogeographic patterns and gene flow? Biological Journal of the Linnean Society 70: 89-105. https://doi.org/10.1111/j.1095-8312.2000. tb00202.x

Wilke T., RolÁN E., DAVIS G. M. 2000. The mudsnail genus Hydrobia s.s. in the northern Atlantic and western Mediterranean: a phylogenetic hypothesis. Marine Biology 137: 827-833. https://doi.org/10.1007/ s002270000407

Wilke T., DAVIS G. M., FALNIOWSKI A., GIUSTI F., BODON M., SZAROWSKA M. 2001. Molecular systematics of Hydrobiidae (Mollusca: Gastropoda: Rissooidea): testing monophyly and phylogenetic relationships. Proceedings of the Academy of Natural Sciences of Philadelphia 151: 1-21. https:// doi.org/10.1635/0097-3157(2001)151[0001:MSOHMG]2.0.CO;2

XIA X. 2000. Data analysis in molecular biology and evolution. Kluwer Academic Publishers, Boston, Dordrecht \& London.

XIA X. 2013. DAMBE: A comprehensive software package for data analysis in molecular biology and evolution. Molecular Biology and Evolution 30: 1720-1728. https://doi.org/10.1093/molbev/mst064

Xia X., Xie Z., Salemi M., Chen L., Wang Y. 2003. An index of substitution saturation and its application. Molecular Phylogenetics and Evolution 26: 1-7. https:// doi.org/10.1016/S1055-7903(02)00326-3

Received: May 9th, 2019

Revised: July 11th, 2019

Accepted: July 20th, 2019

Published on-line: September 14th, 2019 